\title{
A Narrative Inquiry of Identity Formation of EFL University Teachers
}

\author{
Xiangli Cheng \\ Correspondence: Xiangli Cheng, College of Foreign Languages and Literature, Wuhan University, Wuhan, China
}

$\begin{array}{lc}\text { Received: January 18, } 2016 & \text { Accepted: February 1, } 2016 \quad \text { Online Published: February 15, } 2016 \\ \text { doi:10.11114/jets.v4i5.1383 } & \text { URL: http://dx.doi.org/10.11114/jets.v4i5.1383 }\end{array}$

\begin{abstract}
Drawing on narrative inquiry, the present study aims to investigate the trajectory of identity formation of EFL university teachers. Two types of data are collected. One type comes from life histories of Hyland (2014), Nunan (2011) and Widdowson(2009), and the other type comes from semi-structured interviews with three excellent university teachers. With the first group of data, a thematic analysis of narratives is conducted. With the second group of data, a narrative analysis is done. The trajectory of identity formation for the first group is linear, revealing the three renowned applied linguists transforming from inexperienced EFL teachers to $\mathrm{PhD}$ researchers, and ultimately to applied linguists specializing in a specific field. Sharing similarities to the first group in the first two stages, the trajectory of identity formation for the second group is more like a loop, which is characterized as both an EFL learner and an EFL teacher through the entire career.
\end{abstract}

Keywords: analysis of narratives, narrative analysis, teacher identity, EFL teaching

Stories are imaginative enactment of life (Brooks C \& Warren R. P., 2004). They constitute a way for a man to understand the world, embody lived experiences and pass on cultural legacy. In their broadest sense, stories transcend the narrow scope as a literary genre to entertain and inform. They can serve as a means to construct life experience in social science too. Therefore, social science has witnessed what is sometimes called a "narrative turn"(Barkhuizen G., Benson P. \& Chik A., 2014 ). Narrative research proliferated especially in the study of teachers' professional lives and careers in the last several decades (Clandinin \& Connelly, 2000; Norton B. \& Early M. 2011; Tsui A. B. M., 2007; Xu \& Liu, 2009). Yet it is seldom applied to the field of applied linguistics in China until recently, not to mention in the context of foreign language teaching in China (Qian \& Chen, 2014). In the present paper, the author employs narrative approach both as a means to investigate data of language teachers' teaching experiences and as a medium to report data.

\section{Relationship between Narrative Inquiry and the Study of Teacher Identity}

Ontologically, narrative inquiry is strongly influenced by John Dewey, who emphasized experience as both personal and social. An understanding of an individual cannot be fully captured without its relation to others in the social context. Inspired by Dewey and informed by their own fieldwork and research in education, Clandinin \& Connelly (2000) explored the possibility of doing narrative research by creating a metaphorical three dimensional space, with temporality as one dimension, the personal and social space as the second dimension and place as the third. Any individual's experience, whose continuity and wholeness is essential in educational studies, can be narrated in this model of three dimensions. In simpler terms, one's experience is associated with his/her past experience (temporality) in relation to other individuals (sociality) at a certain place. Without these three dimensions, a narrative inquiry cannot properly guarantee the transparency of the data collection process, and therefore may jeopardize the validity of narrative data.

Situated in the broader turn towards qualitative research and post-modern concern with self, identity and individuality, narrative inquiry is welcome and readily adopted by applied linguists in the field of foreign language teaching. TESOL Quarterly issued a special issue to address narrative research in TESOL in 2011, among which identity research was not neglected or dismissed as irrelevant by the editors in their selection. Earlier in the same journal, Tsui (2007) used narrative inquiry to examine how her participant Minfang's identity evolved from "marginal EFL student" to "model CLT teacher," and the complex process associated with the formation of professional identity. Narrative inquiry, focusing on the landscape of teacher's experience, fostered the flourishing development of the study of teacher's professional development in the last decade.

Reviewing literature on the topic of teacher identity, Tsui (2007) summarized three major issues, namely, the multidimensionality or the multi-faceted nature of professional identities and the relationship between these dimensions 
or facets, the relationship between personal and social dimension of identity formation, and the relationship between agency and structure in identity formation. Relatively little attention, however, has been given to the trajectory of identity formation of successful EFL teachers from different social contexts.

In this article, the author adopts narrative approach to examine the trajectory of identity formation of successful EFL teachers by comparing two groups of teachers. One group consists of such world famous figures as Hyland, Nunan, Widdowson. The other group comprises of three excellent EFL teachers from a key university in central China. The professional development of these two groups of EFL teachers may shed some light on the formation of teachers' identity from which the novice EFL teacher may benefit.

\section{Methodology: Narrative Inquiry of Identity Formation}

The search for the trajectory of identity formation of EFL teachers was conducted through a narrative inquiry. According to Clandinin \& Connelly (2000), narrative inquiry is stories lived and told. Teachers draw on their stories to make sense of their life and themselves. Their identities are theorized in the process of telling and retelling of their stories. As discussed earlier, the formation of teacher identity does not happen in a vacuum. It happens in a three dimensional space backwards and forwards, inwards and outwards, and at a certain place. By inwards, it means the internal conditions, such as hope, frustration, moral dispositions and so on. By outwards, it means toward existential conditions, that is the environment. By backward and forward, they mean temporality --- past, present and future.

Identity is both dynamic and relational. In other words, who we are as humans varies according to who we are talking to, where, and for what purposes. The storied lives of our identity formation evolve with meaningful interaction with significant others over a period of time at specific contexts. Therefore, narrative inquiry, with little doubt, helps illuminate how identities are constructed in situated contexts. The three dimensional space advanced by Clandinin \& Connelly (2000) provides a reasonable framework with which EFL teachers' stories can be analyzed.

In this study, the author has collected data from two sources to investigate identity formation. One source is EFL teaching histories published as the prefaces to collections of selected works written by well-known applied linguists. The other source is interview data conducted over a period of half an hour to an hour respectively with each of the three excellent EFL teachers. The author didn't focus on one group of EFL teachers for the following reasons. Firstly, the main concern of this study is the trajectory of identity formation rather than how to become a good or successful EFL teacher. The trajectory of identity formation derived from the two groups may converge. If so, it may become meaningful blueprint for average EFL teachers to reflect on their own experiences. Secondly, many EFL teachers experience a burnout period after years of teaching. They are in great need for insightful guidance for who they really are instead of drowning themselves in dull routine work. Thirdly, EFL teaching faces a transitional period in China when Chinese is gaining more weight over English in the reform of high school curriculum. Meanwhile, College English teaching is faced with the challenge of less course credits and shorter hours of classroom instruction. Many EFL university teachers feel at a loss about their identity, especially when their work is prejudiced as unimportant. So, in a way, the trajectory of identity formation of these two groups may serve as guidance for EFL teachers to draw strength on in China.

\section{EFL Teaching Histories and Interview Data as Narrative Inquiry Data}

Some researchers distinguish "narrative analysis" from "analysis of narratives". For example, Polkinghorne (1995) used "analysis of narrative" to refer to research in which stories are used as data, while "narrative analysis" was used to refer to research in which storytelling is used as a means of analyzing data and presenting findings (quoted from Barkhuizen G., Benson P. \& Chik A., 2014). Despite the distinction drawn between these two terms, they both fall under the umbrella term of narrative inquiry. They provide convenience for the analysis of two types of data in this study, i.e. EFL teaching histories and interview data.

EFL teaching histories used in this study are written accounts of the EFL teaching experiences of three renowned applied linguists. The histories cover their entire teaching career until the retirement. These narratives will be used as data for "analysis of narratives". Interview data, coming from three excellent EFL teachers who have been EFL teachers over 20 years, on the other hand, will be used as data for "narrative analysis" so that their stories can be reported and meanings can be revealed thereafter.

\section{Analysis of Narratives: EFL Teaching Histories of Hyland, Nunan and Widdowson}

The teaching histories discussed in this study come from the personal account of Hyland (2014), Nunan (2011) and Widdowson (2009), which are more or less in the form of narrative. Therefore, they can be accounted as narrative data. Non-narrative data, on the other hand, is not yet in story form. It consists, for example, of interview transcripts, which will be discussed in the following section. Following Polkinghorne (1995), the author conducts an analysis of narrative here, aiming to find the trajectory of identity formation derived from histories of these three distinguished applied linguists. 
Polkinghorne (1995) uses the term "paradigmatic" to describe the characteristic mode of analysis of narrative data. Paradigmatic analysis is largely a matter of categorization and classification, in which particular instances of phenomena are linked to more general concepts. Gao (2010) uses paradigmatic analysis to investigate published autobiographical narratives written by Zhang Haidi, aiming to explore the reasons for her success in terms of characteristics of autonomous learning. He coded and reconstructed the narratives under the themes of motivational discourse, language learning beliefs, and strategic efforts. Gao's study exemplifies the use of thematic analysis. Besides single case study as Gao's study, thematic analysis is suitable for multiple case studies, because it helps develop general knowledge about a collection of stories. In this vein, the writer will attempt to adopt the approach of thematic analysis for the analysis of narratives of EFL Teaching histories.

From 2009, Foreign Language Teaching and Research Press started to introduce selected works of ten applied linguistics. Similarly, in 2011, Shanghai Foreign Language Education Press introduced a collection of articles in book form, each of which addressed a specific area of research in applied linguistics. All these renowned applied linguists were invited to write a summary of their academic career in one chapter or as a preface. Some researchers such as Susan Gass (2009) and Ruqaiya Hasan (2011) orient their autobiographic prefaces to their academical research work, while other researchers such as Hyland (2014), Nunan (2011) and Widdowson(2009) narrate things past both as a EFL teacher and a researcher, targeting to a wider readership. Their narratives of EFL teaching stories are convenient data for narrative inquiry. Therefore, their narratives are selected for thematic analysis.

Three general themes emerge after a careful reading of the narratives of Hyland (2014), Nunan (2011) and Widdowson(2009) with regard to their identity development. These three themes are crosschecked by another experienced researcher, though disagreement occurs on whether it is necessary to further categorize identities. Therefore, the present article focus on the general themes, namely their identities as inexperienced EFL teachers, dual identities as both a PhD/MA student and a teacher, and identities as applied Linguist, curriculum designer, and textbook compiler/writer.

\subsection{Identity as Inexperienced EFL Teachers}

Hyland (2014) starts his narrative by supporting a view of identity that states individuals are not a bundle of particular characteristics such as sincerity, vanity, selfishness or whatever, but the sum of the stories they tell about themselves. Widdowson(2009) starts his narrative by denying the effectiveness of recording chronological events in sequence. Instead, he gives events structure by identifying thematic continuities and developments in thinking. Nunan (2011) starts his narrative by narrating directly what happened on the first day of being a school teacher. All of them record important moments in their life, unanimously choosing stories as a means to make sense of the past from the perspective of the present.

Nunan's first lesson was chaotic at Temple Boy's high school in 1972. He was five-minutes late and didn't win much respect from the disruptive boys. His plan was to initiate high school students into the mysteries and joys of literature for the next three to five years and, at the same time, to write the Great Australia Novel. Faced with undisciplined immigrant kids, the plan didn't go well. He was even stabbed by a boy named Bruno after the boy's father was summoned to school for a warning of suspension.

Luckier than Nunan, Widdowson didn't need to face disruptive boys. He was dispatched to a university in Indonesia to teach his beloved literature in 1958. Contrary to his expectation of becoming a literature lecturer to teach his literature, he had to be a language teacher first of all since his students were baffled by the literary texts. Later on in the early 1960s he was appointed by the British council to work in Sri Lanka and Bangladesh as an Education Officer.

The least chaotic experience was provided by Hyland who was granted a job in Sudan after sending out 60 application letters in 1977. The problems for him were dirt floors, few books and a lot of students. With over 90 boys in each class, he had to manage language drills when only the first three rows had the chance to practice.

From the narratives of the starting years of their careers, it can be safely concluded that they were inexperienced teachers without much professional training. No achievements of their students were discussed in their stories. Their beginning in the career of language teaching was as bad as anyone novice teacher. However, the fortunate thing for them was they were pioneers at the less-tilled frontier of EFL teaching, who were destined to glorious achievement if they aimed high enough and worked hard enough. Furthermore, another bonus for them was that they were native speakers of English, which made them easier to be a language model for their non-native learners.

\subsection{Dual Identities as Both A Phd/MA Student and A Teacher}

After engaging as an EFL teachers for several years, all three of them, Nunan, Widdowson and Hyland embarked on their academic journey. In 1964 Widdowson went to Edinburgh where pioneers in applied linguistics worked and taught, including such individuals as Michael Halliday, John Lyons and Pit Corder. Reflecting on his years in Bangladesh, 
Widdowson wrote a dissertation on what is now known as Content and Language Integrated Learning, which was novel at the time. Later, Widdowson worked in Edinburgh and it was a period of enthusiastic intellectual journeying. In 1973, Widdowson completed his doctorate. The motivation for his doctorate work was from his teaching experience, which was a recognition of the communicative needs of students learning English for specific purposes. Again, it was creative and original at the time.

The intellectual journey for Nunan was not as smooth as Widdowson's. After working with different groups of learners, Nunan felt the urge to develop deeper insight into the social and psychological processes involved in learning a second language. As a result, he went to England for a postgraduate diploma in 1970s. Unfortunately, it was not a fruitful experience, so Nunan came back to Australia because of his dwindling budget. There he met Mike Golby from the Open University, who suggested a master's degree in curriculum studies under his supervision. Later on, Nunan's pursuit for doctorate was as edgy as his master's. After being forced to change a supervisor because of his invisibility, he was under the supervision of Jonathan Anderson. Nunan was intrigued by Halliday's work and started his doctorate study in discourse analysis. In the end he got his degree after an undue wait for the examiners' report. The most striking thing for Nunan was he was running a new graduate program and completing a Ph.D at the same time, both of which were mentally exhausting.

Somewhat feeling a similar urge as Nunan, Hyland was frustrated by the inefficiency of the PPP model. He applied for an MA program jointly run by Malaysia and the University of Birmingham. Hyland developed a passion for discourse analysis and was introduced to corpus linguistics in its early form. He completed his MA dissertation on conversation interaction, which was beneficial to later work and research. In the 1990s, Hyland worked further on the topic of hedging for his PhD study. Drawing on earlier experience with corpus, he developed his own categorization system and got encouragement from John Swales and Janet Holmes.

The pursuit of MA and PhD of all the three applied linguists are motivated for the inner need for more knowledge in EFL teaching. The job need for a degree comes second. So in a way, the degree consolidates their identity as a good EFL teacher, while they all find themselves a research interest which they pursue over their lifetime.

\subsection{Identities as Applied Linguist, Curriculum Designer, and Textbook Compiler/Writer}

As the oldest of the three, Widdowson's academic work is a pioneering one in applied linguistics. Much of his research is seminal and influential for later applied linguists. After the completion of his doctorate work, Widdowson wrote a book called Stylistics and the Teaching of Literature in 1975. Following his work on his doctorate thesis, Widdowson collaborated with Patrick Allen and together they designed and published the English in Focus series. His book Teaching Language as Communication, promoting a communicative orientation to language teaching and learning in general, is still in print and being read after its publication thirty years later. Besides these two books, Widdowson continued to publish prolifically on language teacher education (Language Teaching: A Scheme for Teacher Education), language teaching materials (Aspect of Language Teaching), stylistics (Practical Stylistics: An Approach to Poetry), and so on.

Influenced by David Wilkins and Henry Widdowson, Nunan published his first book Course Design: Trends and Issues after the completion of his doctorate thesis. Then came his first international publication, which appeared as The Learner-centered Curriculum. More of his publications dealt with EFL teaching, such as Understanding Language Classrooms, Language Teaching Methodology, and Designing Tasks for the Communicative Classroom. His textbook writing includes the fourth and final level of ATLAS. Nunan's publications are widely read by both EFL teachers of native speakers and non-native speakers.

Hyland's academic journey as a peripheral participant started with his doctorate study on hedging from 1990 to 1995. Then he gained voice by getting several hedging-related papers published in important journals, such as Written Communication, English for Specific Purposes, Applied Linguistics and System. He even launched the first issue of Journal of Academic Purpose together with Liz Hamp-Lyonz and Elsevier. Through the late 1990s and early 2000s, Hyland wrote papers on acknowledgements (e.g. Hyland, 2003), undergraduate theses (Hyland, 2006), book reviews (Tse \& Hyland 2006), dissertations (Hyland, 2004), journal descriptions (Hyland \& Tse, 2009), and so on.

While publishing in their respective research fields, Widdowson, Nunan and Hyland assume new identities as applied linguists, curriculum designers, textbook writers/compilers, and program directors. Their teaching career has come to a mature stage until their retirement.

\section{Narrative Analysis of Interviews with Three EFL Teachers}

Data collected for this section do not count as narrative as it happens in the last section when EFL teaching histories are presented, from which the author draws upon. Here the data come from three interviews conducted by the author with three excellent EFL university teachers. By excellent it means that they have either won the first prize in EFL teaching 
contest at the provincial level and national level or they have ranked among the top 5\% by student's rating of teaching performance at the end of each term. The interview questions collect data about the past experiences of language teaching, education background and how these three teachers evaluate the evolving textbooks. So this section presents a new set of data with a new group of research subjects, which will provide complementary insight to the investigation of trajectory of identity formation in comparison to the last section.

As mentioned earlier, this section will focus on narrative analysis of non-narrative data. Polkinghorne (1995) describes "narrative analysis" as studies whose data consist of actions, events, and happenings, but whose analysis produces stories. Here three stories will be reconstructed from the interview data, each of which concentrates on a specific aspect of teacher development with regard to the identities of EFL university teachers as practitioners. The names are pseudonyms for ethical concerns.

\subsection{Betty's Story}

I'm 46 years old. I started College English teaching in 1995, in which it was not called in its present name. At that time College English was paid more than enough attention to by universities throughout China, and I felt proud of being a College English teacher. However, things didn't go as seemed right. Around 2000, College English teaching was criticized by top officials from the Ministry of Education for its low efficiency and high cost of time and energy. Right then I went abroad to pursue my MA and PhD study, so I wasn't quite aware of the scale and effectiveness of College English reform then. After I came back to China with my $\mathrm{PhD}$ degree, I shifted my attention to the training of critical thinking rather than specific language skills in my class. Critical thinking was and is highly valued by EFL/ESL teachers abroad. I didn't attach so much attention to British or American accent as I had done before, if only the accent was intelligible. Since the past several years I started to feel the pressure of research demand from the University. Without academic publications or research projects on hand, a College English teacher is not considered as a qualified teacher, not to mention an excellent teacher. So I focus more of my attention on research, with adequate attention to teaching of course. However, teaching is not my priority as I did in the past.

\subsection{Mary's Story}

I'm 42 years old. I started College English teaching in 1996. At the beginning my class was teacher-centered and crammed with grammar-translation exercises, which was the trend and was the way I learned English at university when I was a university student. Two years later I was awarded 500 yuan because of the high passing rate of CET-4. It was a big sum then. I bought a new bike because my student laughed at me for the old broken bike I rode to university every day. Around 2003 I began my MA study because most of my colleagues had either gotten a MA degree or were in the process of doing it. Two years later after my graduation, I started my PhD study. Sometimes I wonder who I am as a College English teacher. To help my students to pass CET test, TOFEL or GRE test? No. I want to let them know they are not a test -taking machine. I need to have my own style of teaching. The older I am, the more I love my job. I learn in the process of teaching. The gap of age between me and my students is getting wider and wider. I'm like a mother to them, so I understand what they need from me. Now I've got my $\mathrm{PhD}$ degree in Chinese literature. In class I make every effort to empower my students with my own teaching and living style. I am a learned scholar standing right before them. They may forget what I've taught them years later, but they can remember me as a teacher, my style of living and teaching.

\subsection{Elizabeth's Story}

I'm 45 years old. I started College English teaching in 1991. Once I taught a textbook called Experiencing English, which had an impact on my teaching. Of course the ultimate goal of the textbook was to use English, to learn the four skills. But in experiencing English, the students developed love for English learning. We shared things, such as dancing and singing. My students and I were bonded together as sharers rather than stay in the hierarchical relationship of a teacher and students. Such a direct involvement promoted more language learning. Around 2001, I went to Singapore to study in a MA program. There I learned professionalism, dedication to teaching and respect for students. Teaching is an encounter of two living individuals when they are destined to be together for some time. This experience has an everlasting impact on my teaching. Now in my class, I will stop students from learning for a high score. I tell them that English may help them to see the world with a new perspective. They can learn some beautiful words, such as dignity, humanity, altruism, generosity, and integrity. My students do not just learn the spelling of these words. They learn to face tough moments in their life with the help of these words. I once shared a line from the song Hope with my students, "With compassion and care we create hope". Because of alliteration, the sentence is both musical and meaningful.

Now College English is neglected by society and university because there is call for reduction of course credits and instruction time. It frustrates me. I once asked my students the question about what they'd like to have at university, a teacher, a tutor, or a mentor. I told my students that I was trying to be a mentor to them. They could learn more than language from me. It's a rewarding experience for them. After more than twenty years of teaching, I have my own 
teaching philosophy and an inner peace of mind. I'd like to be a teacher my students can look up to, so I keep learning all sort of things, not only the English language, but also history, philosophy, religion and so on. The outside world has changed me little. It never will.

\section{Discussion}

The expanding use of narrative analysis in social science does not claim to offer a single, unified theory, but is rather an orientation that aims at examining the nature and role of narrative in human life, experience and thought. In writing Remembrance of Things Past, Widdowson (2009) makes sense of the past from the perspective of the present, imposes an order upon it not apparent at the time of writing. In writing A Very Peculiar Practice, Hyland (2014) thinks of stories in his life as important because looking back, some of the choices come to look like a coherent direction to some goal. For us readers, especially for the author, their narratives provide a picture of their path to becoming a successful EFL teacher and an academic.

Despite the diversity in their teaching experiences in different parts of Asian countries and their own native countries, and despite variance in expertise in applied linguistics, the narratives of Widdowson, Nunan and Hyland reveal that the trajectories of identity formation seem to converge. They start as an inexperienced EFL teacher without much formal training in language teaching. Later on after years of teaching in some foreign countries, they decide to pursue MA study and PhD study to gain strength in language teaching and foster a passion in a research area. Their careers come to a peak when their voices are heard internationally, especially after their international reputation is built by publications.

The stories of three excellent EFL university teachers come from a different language teaching landscape. First of all, this group of teachers are non-native speakers. As a result, their identities as language learners remain constant throughout their teaching career. Language learners and language teachers label them as a peculiar group of EFL teachers. Secondly, their pursuit of MA or PhD degrees is driven less for an urge of more knowledge about how a language is learned, but more for a need for promotion or competition in a teaching community crowded with equally competent teachers. They have more empathy with their students about how EFL is learned and they can predict language learning difficulties from their own learning experiences. Lastly, their identity as a College English teacher does not help them gain recognition in China where English is understood as a tool, which can be taught by anyone at any place, even at some private training centers. However, this group of teachers do not belittle their work. They endeavor conscientiously to inspire their students, to make a life-long impact on their students while teaching English as a foreign language.

By comparison, it can be seen that the trajectories of identity formation of the second group is different from the first group. Their trajectories are less of a linear progression, but more like loop. They start their career both as EFL teachers and EFL learners. Then they pursue their MA and PhD study, with EFL learning continued. Lastly, they are searching to redefine themselves as EFL university teachers when their work is not fully recognized under the current evaluation criteria of university teachers in China.

\section{Conclusion}

Similar to other qualitative studies, the findings in the present study are not objective. The author acknowledges that the findings are interpretive in nature. To guarantee rigor, the author looks carefully at the two types of data, the EFL teaching history and interview data, and adopts two approaches to analyze them, the analysis of narratives and the narrative analysis. The author also invited an experienced researcher to double check the emerging themes of life histories for thematic analysis. To ensure trustworthiness, the author acknowledges that there is distinction between "life as lived, life as experienced and life as told". What is interpreted is life as told, therefore, there is inherent subjectivity with regard to the teller of the stories. As for generalizability, the author believes the aim of narrative inquiry is contribution to knowledge with rich description of cases, so a generalizable theory is not the aim of the present narrative inquiry. Despite all the seeming limitations, EFL teachers at large can still find resonance of voices unheard of in quantitative studies, where EFL teacher's individuality is hidden in statistical numbers.

\section{References}

Barkhuizen, G., Benson P., \& Chik A. (2014). Narrative Inquiry in Language Teaching and Learning Research. New York: Routledge.

Brooks, C., \& Warren R. P. (2004). Understanding Fiction. Beijing: Foreign Language Teaching and Research Press.

Clandinin, D. J., \& Connelly, E. M. (2000). Narrative Inquiry: Experience and Story in Qualitative Research. San Francisco: John Wiley \& Sons Inc.

Gao, X. (2010). Autonomous Language Learning Against All Odds, System, 38, 580-590. http://dx.doi.org/10.1016/j.system.2010.09.011 
Gass, S. (2009). Selected Works of Susan Gass on Applied Linguistics. Beijing: Foreign Language Teaching and Research Press.

Hasan, R. (2011). Selected Works of Ruqaiya Hasan on Applied Linguistics. Beijing: Foreign Language Teaching and Research Press.

Hyland, K. (2003). Dissertation Acknowledgments: The Anatomy of Cinderella Genre. Written Communication, 20(3), 242-268. http://dx.doi.org/10.1177/0741088303257276

Hyland, K. (2004). Disciplinary Interactions: Metadiscourse in L2 Postgraduate Writing. Journal of Second Language Writing, 13, 133-151. http://dx.doi.org/10.1016/j.jslw.2004.02.001

Hyland, K. (2006). Representing Readers in Writing: Student and Expert Practices. Linguistics and Education, 16, 363-377. http://dx.doi.org/10.1016/j.linged.2006.05.002

Hyland, K. (2014). Academic Written English. Shanghai: Shanghai Foreign Language Education Press.

Norton, B., \& Early, M. (2011). Researcher Identity, Narrative Inquiry, and Language Teaching research. TESOL Quarterly, 45, 415-440. http://dx.doi.org/10.5054/tq.2011.261161

Nunan, D. (2011). Selected Works of David Nunan on Applied Linguistics. Beijing: Foreign Language Teaching and Research Press.

Polkinghorne, D. E. (1995). Narrative Configuration in Qualitative Analysis. Qualitative Studies in Education, 8, 5-23. http://dx.doi.org/10.1080/0951839950080103

Qian, X. X., \& Chen, M. Y. (2014) A Study of Foreign Language Teachers from the Perspective of Educational Narrative Approach: History and Reflections. Foreign Language World, 160(1), 49-57.

Tse, P., \& Hyland, K. (2006). "So What is The Problem This Book Address?" Interactions in Book Reviews. Text and Talk, 27, 767-790. http://dx.doi.org/10.1515/TEXT.2006.031

Tse, P., \& Hyland, K. (2009). Discipline and Gender: Constructing Rhetorical Identity in Book Reviews. In Hyland, K., \& Diani, G. (Eds). Academic Evaluation: Review Genres in University Settings. (pp. 105-121). London: Palgrave-MacMillan.

Tsui, A. B. M. (2007). Complexities of Identity Formation: A Narrative Inquiry of an EFL Teacher. TESOL Quarterly, 41, 657-680. http://dx.doi.org/10.1002/j.1545-7249.2007.tb00098.x

Widdowson, H. (2009). Selected Works of Henry Widdowson on Applied Linguistics. Beijing: Foreign Language Teaching and Research Press.

Xu, Y. T., \& Liu, Y. C. (2009). Teacher Assessment Knowledge and Practice: A Narrative Inquiry of a Chinese College EFL teacher's experience. TESOL Quarterly, 43, 493-513. http://dx.doi.org/10.1002/j.1545-7249.2009.tb00246.x

\section{$(\mathrm{cc}) \mathrm{BY}$}

This work is licensed under a Creative Commons Attribution 3.0 License. 